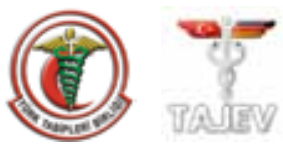

\title{
Clinical value of DNA fragmentation evaluation tests under ART treatments
}

\author{
Yardımcı Üreme Teknikleri tedavilerinde sperm DNA fragmentasyonu \\ değerlendirilmesinin klinik etkileri
}

\author{
İlkay Şafak Tavukçuoğlu, Tahani Al-Azawi, Amir Afshin Khaki, Arash Khaki, Ahmed Khalil, Safaa Al-Hasani \\ Reproductive Medicine Unit, University of Schleswig-Holstein, Luebeck, Germany
}

\section{Abstract}

Male reproductive health has been under scrutiny recently. Many studies in the literature have concluded that semen quality is declining and that the incidence of testicular cancers is increasing. The reason for this change has been attributed to damage in sperm chromatin. During in vivo reproduction, the natural selection process ensures that only a spermatozoon with normal genomic material can fertilize an oocyte. However, the assisted reproduction technique (ART) is our selection process, leading to the possibility that abnormal spermatozoa could be used to fertilize an oocyte. We could avoid this by quantifying the amount and type of genomic damage in sperm using well-accepted laboratory methods. The sperm deoxyribonucleic acid (DNA) integrity is important for success of natural or assisted fertilization as well as normal development of the embryo, fetus and child. Intra cytoplasmic sperm injection (ICSI) is bypassing natural sperm selection mechanisms, which increases the risk of transmitting damaged DNA. The significance of required investigations and multiple techniques is that they could evaluate DNA defects in human spermatozoa. The ability of these techniques to accurately estimate sperm DNA damage depends on many technical and biological aspects. The aim of this review is to evaluate the most commonly used methods.

(J Turkish-German Gynecol Assoc 2012; 13: 270-4)

Key words: Tunel, Comet, Acridine Orange staining technique (AOT), Sperm Chromatin Dispersion (SCD), Sperm Chromatin structure (SCSA)

Received: 10 October, 2012

Accepted: 30 November, 2012

\section{Özet}

Erkek üreme sağlığıyla ilgili son zamanlardaki çalışmalar semen kalitesi ve sıklığı artan testiküler kanser vakaları üzerinde yoğunlaşmaktadır. Normal üreme şartlarında spermlerin doğal seleksiyonu söz konusu olmakta ve normal genetik yapıdaki spermlerle oositlerin fertilizasyonu gerçekleşmektedir. Ancak yardımcı üreme teknikleri ile gerçekleştirilen tedavilerde sperm seçimi semen kalitesine bağlı olarak da anormal spermlerle geçekleştirilebilmektedir. Bu durumlarda kabul görmüş birtakım laboratuvar testleri uygulayarak hasarlı genetik yapıdaki spermlerden korunabilmek mümkün olabilmektedir. Sperm deoksiribonükleik asid (DNA) bütünlüğü; doğal ve yardımcı yöntemlerle fertilizasyonun başarısı aynı zamanda embriyo, fetüs ve çocuğun normal gelişimi için önemlidir. İntrasitoplazmik sperm enjeksiyonunda (ICSI) doğal sperm seçim mekanizmalanı devre dışı kalmakta, bu da hasarlı DNA'nın transfer riskini artırmaktadır. Bu derlemede sperm DNA fragmantasyonu oranı belirlemede en sık kullanılan testler değerlendirilmektedir. (J Turkish-German Gynecol Assoc 2012; 13: 270-4)

Anahtar kelimeler: Tunel, Comet, Acridine orange boyama tekniği (AOT), sperm kromatin dağılımı testi (SCD), sperm kromatin yapı testi (SCSA)

Geliş Tarihi: 10 Ekim 2012

Kabul Tarihi: 30 Kasım 2012

\section{Introduction}

Sperm quality is ferquently used as an indirect measure of male infertility. The parameters that have been used historically as indicators of male infertility potential include sperm count, motility and morphology, all of which are evaluated in fertility clinics as a part of routine semen analyses (1). Assisted reproductive techniques such as conventional in vitro fertilization (IVF) and intra cytoplasmic sperm injection (ICSI) allow couples whose sperm parameters are impaired to achieve a pregnancy. Among these factors which are involved in the failure to obtain embryos and pregnancies, the impaired sperm genom is frequently incriminated $(2,3)$.
To assist in the risk assesment of ICSI, it would be appropriate to develop methods to measure deoxyribonucleic acid (DNA) damage in the sperm and to correlate this with biological outcomes. DNA abnormalities in sperm are well documented. Cytogenetic analysis of sperm chromosomes has demonstrated sperm aneuploidy, which, although low in frequency, is assosciated with infertility and adverse pregnancy outcome $(4,5)$. Several techniques and investigations are proposed in order to study these abnormalities. Those which are currently used are; the Tunel test, which allows the evaluation of the sperm DNA fragmentation $(6,7)$, the Comet test, which represents another way of evaluating the DNA integrity $(8,9)$ and DNA staining by acridine orange (AO), which differenti-

Address for Correspondence: Safaa Al-hasani, Reproductive Medicine Unit, University Of Schleswig-Holstein, Luebeck, Germany Phone: +4945150002145 e.mail: sf_alhasani@hotmail.com

(C) Copyright 2012 by the Turkish-German Gynecological Education and Research Foundation - Available online at www.jtgga.org doi:10.5152/jtgga.2012.44 
ates between single and double stranded DNA based on their reactive colors under fluorescence and thus allows the degree of DNA denaturation to be evaluated (3). Other tests identify the packaging defects of sperm chromatin: aniline blue staining, toluidine blue staining, and chromomycin A3 staining (10).

\section{Sperm DNA and Abnormalities}

Deoxyribonucleic acid of sperm is organized in a special way that keeps the nuclear chromatin compact and stable (11). This DNA not only permits the tightly packaged genetic information to be transferred to the oocyte but also ensures that the DNA is delivered in a physical and chemical form that allows the developing embryo to easily access the genetic knowledge. Fertile and normal sperm have stable DNA, which is able to undergo decondensation at the same time in the fertilization process and transmit the DNA without defects.

Defective genomic material in sperm may cause the formationof condensation or nuclear maturity defects, DNA breaks, DNA integrity defects, or sperm chromosomal aneuploidies (12). The causes of these defects have been attributed to disease, drug use, high fever, more than normal testicular temperature, smoking, and advanced age. DNA damage's molecular mechanism in these different conditions is under intense investigation. The most important mechanisms for sperm DNA damage are abnormal chromatin packaging, reactive oxygen species (ROS) (13), and apoptosis $(14,15)$. It is likely that multiple mechanisms are involved, based on the clinical diagnosis responsible for DNA damage.

\section{Comet Assay}

Comet assay uses single cell gel electrophoresis (SCGE) to analyze DNA fragmentation in individual cells, was first introduced in 1984 by Ostling and Johanson (16) who used neutral buffer conditions to study double-stranded DNA breaks (17). This assay is extensively used in somatic cells to measure genotoxic damage, especially single and double strands breaks and was originally applied to sperm by Singh (18). The Comet assay may therefore be used to study single or double stranded DNA breaks in somatic cells or germ cells and is useful because it allows for the distinction between the different kinds of DNA fragmentation necrotic and appoptotic cells. Appoptotic cells produce teardrop shape comets during electrophoresis (19). The shape is due to the migration and accumulation of the short DNA fragments and the intensity of the tail represents the amount of DNA fragments present (20).

\section{Tunel Test}

This test was originally described by Garvrieli, Sherman, and Ben-Sasson in 1992 (21). Tunel has become one of the main methods for detecting apoptotic programmed cell death. However, there has been a debate about its accuracy, due to problems in the original assay, which caused necrotic cells to be inappropriately labeled as an apoptosis (22). The method has subsequently been improved dramatically to identify only cells in the last phase of apoptosis $(23,24)$. New methods incorporate the dUTPs modified by fluorophores or haptens, including biotin or bromine, which can be detected directly in the case of a fluorescently-modified nucleotide (fluorescein-dUTP), or indirectly with streptavidin or antibodies, if biotin-dUTP or BrdUTP are used, respectively.

The TUNEL assay detects both single- and double-stranded DNA breaks by labeling the free $39-\mathrm{OH}$ terminus with modified nucleotides in an enzymatic reaction with terminal deoxynucleotidyl transferase (TdT) and can be analyzed microscopically or by using flow cytometry.

Acridine orange staining technique (AOT), sperm chromatin dispersion (SCD) and sperm chromatin structure (SCSA) tests The acridine orange staining technique (AOT) is a simple microscopic procedure based on the same principle as the sperm chromatin structure assay (SCSA) but indistinct colours, rapid fading of fluorescence, and heterogeneous staining of slides makes AOT a test of questionable value in clinical practice (25). The SCSA is fluorescence activated cell sorter test, measures the susceptibility of sperm DNA heat or acid induced DNA denaturation in situ followed by staining with acridine orange (26).

Recently, a new method, the sperm chromatin dispersion test (SCD), was introduced for evaluating sperm DNA fragmentation (27-37). The SCD test is based on the principle that sperm with fragmented DNA fails to produce the characteristic halo of dispersed DNA loops that is observed in sperm with nonfragmented DNA following acid denaturation and removal of nuclear proteins.

\section{Evaluation of tests used under ART treatments}

Several authors were included to diagnose with the tests results of their differently based researches.

Table 1 shows that some authors had reported a significant relationship between sperm DNA fragmentation index and pregnancy rate $(3,32,34-37)$. On the other hand, many others revealed no significant relationship (9, 28-31). However, these controversial results may be attributed to different principles of the techniques of the analytical methods used, as represented in Table 2. Each assay method has their advantages and disadvantages.

\section{Conclusion}

Sperm DNA integrity is associated with male infertility potential in vivo and in vitro. There are increased levels of fragmented sperm DNA in a high percentage $<40 \%$ of men presenting as clinically subfertile. Especially semen with a high percentage of damaged spermatozoa has a very low potential for natural fertility. DNA damage in sperm does not preclude IVF as there is still a chance that samples in which sperm have damaged DNA can be used to achieve a pregnancy. ART studies mentioned that the reproductive parameters that could be affected by the integrity of the DNA in ejaculated spermatozoa include fertilization, blastocyst development and pregnancy rates. In fact, pregnancy rates using conventional IVF and ICSI treatments are significantly reduced in couples with a high percentage of sperm with DNA damage.

All literature shows that sperm DNA damage influences the fertility outcome to different degrees, but there is no consensus 
Table 1. The statistical relationship between sperm DNA fragmentation index (DFI \%) and pregnancy rate with different analytical tests under ART treatments as reported by some authors

\begin{tabular}{|c|c|c|c|c|c|}
\hline Authors & DFI \% & ART Procedure & Patient \# & Statistical Results & Analysis \\
\hline Chohan et al. (28) & $<30$ & IVF or ICSI & 52 & Not Significant & SCSA, Tunel, SCD \\
\hline Larson et al. (3) & $<27$ & ICSI & 21 & Significant & SCSA \\
\hline Check et al. (29) & $<30$ & ICSI & 106 & Not Significant & SCSA \\
\hline Morris et al. (9) & Low DNA Damage & IVF or ICSI & 52 & Not Significant & Comet \\
\hline Bungum et al. (30) & $<27$ & IVF & 109 & Not Significant & SCSA \\
\hline Bungum et al. (30) & $>27$ & IVF-ICSI & 66 & Not Significant & SCSA \\
\hline Larson-Cook et al. (31) & $<27$ & IVF & 55 & Not Significant & SCSA \\
\hline Larson-Cook et al. (31) & $<27$ & ICSI & 26 & Not Significant & SCSA \\
\hline Virro et al. (32) & $<30$ & IVF & 249 & Significant & SCSA \\
\hline Spano et al. (33) & $<30$ & In-vivo & 215 & No Result & SCSA \\
\hline Everson et al. (34) & $<30$ & In-vivo & 147 & Significant & SCSA \\
\hline Henkel et al. (35) & $<36.5$ & IVF & 208 & Significant & Tunel \\
\hline Henkel et al. (36) & $<36.5$ & IVF & 167 & Significant & Tunel \\
\hline Caglar et al. (37) & $>4$ & ICSI & 56 & Significant & Comet \\
\hline Caglar et al. (37) & $>4$ & ICSI & 56 & Significant & Tunel \\
\hline
\end{tabular}

Table 2. Evaluation of different analytical tests (principles, detection method, advantages and disadvantages) used in ART treatments

\begin{tabular}{|c|c|c|c|c|}
\hline Assay & Principle & Detection method & Adventages & Disadvantages \\
\hline Tunel & $\begin{array}{l}\text { Single \& double } \\
\text { strand DNA breaks }\end{array}$ & $\begin{array}{l}\text { Fluorescence } \\
\text { microscopy, } \\
\text { Flow cytometry }\end{array}$ & $\begin{array}{l}\text { Clinically significant high sensivity } \\
\text { and specificity large number } \\
\text { of spermatozoa counted by flow } \\
\text { cytometry }\end{array}$ & $\begin{array}{l}\text { Special equipment, } \\
\text { more expensive }\end{array}$ \\
\hline Comet & $\begin{array}{l}\text { Single \& double strand } \\
\text { DNA breaks or only } \\
\text { double strand DNA } \\
\text { breaks }\end{array}$ & $\begin{array}{l}\text { Fluorescence } \\
\text { microscopy }\end{array}$ & $\begin{array}{l}\text { Related to Tunel assay, cheap, } \\
\text { high sensitivity qualification of } \\
\text { DNA damage in individual cells, } \\
\text { evaluation of different type of DNA } \\
\text { damage }\end{array}$ & $\begin{array}{l}\text { Special equipment } \\
\text { and experienced } \\
\text { observer }\end{array}$ \\
\hline $\begin{array}{l}\text { Acridine } \\
\text { Orange }\end{array}$ & $\begin{array}{l}\text { Differentiates between } \\
\text { single \& double } \\
\text { stranded DNA }\end{array}$ & $\begin{array}{l}\text { Fluorescence } \\
\text { microscopy }\end{array}$ & Easy to perform, cheap & $\begin{array}{l}\text { Special equipment } \\
\text { distiction between } \\
\text { differenty labelled } \\
\text { spermatozoa, not } \\
\text { always easy }\end{array}$ \\
\hline $\begin{array}{l}\text { Sperm } \\
\text { Cromatin } \\
\text { Decondensation }\end{array}$ & $\begin{array}{l}\text { Evaluation of DNA } \\
\text { decondensation halo }\end{array}$ & $\begin{array}{l}\text { Fluorescence } \\
\text { microscopy, } \\
\text { Optical microscopy }\end{array}$ & Easy to perform, cheap & $\begin{array}{l}\text { Clinical relevance not } \\
\text { yet proven }\end{array}$ \\
\hline $\begin{array}{l}\text { Sperm } \\
\text { cromatin } \\
\text { stracture } \\
\text { assay }\end{array}$ & $\begin{array}{l}\text { Susceptibility of DNA } \\
\text { to acid denaturation }\end{array}$ & Flow cytometry & $\begin{array}{l}\text { Clinically significant high sensivity } \\
\text { and specificity large number of } \\
\text { spermatozoa counted by flow } \\
\text { cytometry, unbiased quantitative } \\
\text { assessment of DNA bound acridine } \\
\text { orange }\end{array}$ & $\begin{array}{l}\text { Special equipment, } \\
\text { more expensive }\end{array}$ \\
\hline
\end{tabular}


on the technique that should be used to measure sperm DNA in subfertile patients. The methods used to detect sperm DNA damage should be standardized to allow comparison among different studies and to permit routine use of tests in clinical laboratories. The results of degrees of DNA damage could give better decision facilitation to physicians on infertile couples about their chances of having a live birth. New researchs aim to identify the type of DNA defects that affect fertility regardless of the quantity of damaged DNA and to identify and isolate spermatozoa with intact DNA for ART. The TUNEL, AOT, and SCD are simple, less expensive procedures and can be performed in a short period of time to assess the levels of DNA fragmentation in sperm from infertile men and donors of known fertility.

\section{Conflict of interest}

No conflict of interest was declared by the authors.

\section{References}

1. Word Health Organization. WHO Laboratory Manual for the Examination and Processing of Human Seman 5th edn. Cambridge: Cambridge University, 2010.

2. Ahmadi A, Ng SC. Developmental capacity of damaged spermatozoa. Hum Reprod 1999; 14: 2279-85. [CrossRef]

3. Larson KL, DeJonge CJ, Barnes AM, Jost LK, Evenson DP. Sperm chromatin structure assay parameters as predictors of failed pregnancy following assisted reproductive techniques. Hum Reprod 2000; 15: 1717-22. [CrossRef]

4. Egozcue S, Blanco J, Vendrell JM, García F, Veiga A, Aran B, et al. Human male infertility: chromosome anomalies, meiotic disorders, abnormal spermatozoa and recurrent abortion. Hum Reprod Update 2000; 6: 93-105. [CrossRef]

5. Shi Q, Martin RH. Aneuploidy in human sperm: a review of the frequency and distribution of aneuploidy, effects of donor age and lifestyle factors. Cytogenet Cell Genet 2000; 90: 219-26. [CrossRef]

6. Ahmadi A, Ng SC. Fertilizing ability of DNA damaged spermatozoa. J Exp Zool 1999; 284: 696-704. [CrossRef]

7. Barroso G, Morshedi M, Oehninger S. Analysis of DNA fragmentation, plasma membrane translocation of phosphatidylserine and oxidative stress in human spermatozoa. Hum Reprod 2000; 15: 1338-44. [CrossRef]

8. Chan PJ, Corselli JU, Patton WC, Jacobson JD, Chan SR, King A. A simple comet assay for archived sperm correlates DNA fragmentation to reduced hyperactivation and penetration of zona-free hamster oocytes. Fertil Steril 2001; 75: 186-92. [CrossRef]

9. Morris ID, Ilott S, Dixon L, Brison DR. The spectrum of DNA damage in human sperm assessed by single cell gel electrophoresis (Comet assay) and its relationship to fertilization and embryo development. Hum Reprod 2002; 17: 990-8. [CrossRef]

10. Tomlinson MJ, Moffatt O, Manicardi GC, Bizzaro D, Afnan M, Sakkas D. Interrelationships between seminal parameters and sperm nuclear DNA damage before and after density gradient centrifugation: implications for assisted conception. Hum Reprod 2001; 16: 2160-5. [CrossRef]

11. Agarwal A, Said TM. Role of sperm chromatin abnormalities and DNA damage in male infertility. Hum Reprod Update 2003; 9: 331-45. [CrossRef]

12. Perreault SD, Aitken RJ, Baker HW, Evenson DP, Huszar G, Irvine DS, etal. Integrating new tests of sperm genetic integrity into semen analysis: breakout group discussion. Adv Exp Med Biol 2003; 518: 253-68. [CrossRef]
13. Agarwal A, Saleh RA, Bedaiwy MA. Role of reactive oxygen species in the pathophysiology of human reproduction. Fertil Steril 2003; 79: 829-43. [CrossRef]

14. Sakkas D, Mariethoz E, Manicardi G, Bizzaro D, Bianchi PG, Bianchi U. Origin of DNA damage in ejaculated human spermatozoa. Rev Reprod 1999; 4: 31-7 [CrossRef]

15. Shen H, Ong C. Detection of oxidative DNA damage in human sperm and its association with sperm function and male infertility. Free Radic Biol Med 2000; 28: 529-36. [CrossRef]

16. Olive PL, Durand RE, Banáth JP, Johnston PJ. Analysis of DNA damage in individual cells. Methods Cell Biol 2001; 64: 235-49. [CrossRef]

17. Raman RS, Chan PJ, Corselli JU, Patton WC, Jacobson JD, Chan SR, et al. Comet assay of cumulus cell DNA status and the relationship to oocyte fertilization via intracytoplasmic sperm injection. Hum Reprod 2001; 16: 831-5. [CrossRef]

18. Singh NP, Danner DB, Tice RR, McCoy MT, Collins GD, Schneider EL. Abundant alkali-sensitive sites in DNA of human and Mouse sperm. Exp Cell Res 1989; 184: 461-70. [CrossRef]

19. Olive PL, Banáth JPSizing highly fragmented DNA in individual apoptotic cells using the comet assay and a DNA crosslinking agent. Exp Cell Res 1995; 221: 19-26. [CrossRef]

20. Duty SM, Singh NP, Ryan L, Chen Z, Lewis C, Huang T, et al. Reliability of the comet assay in cryopreserved human sperm. Hum Reprod 2002; 17: 1274-80. [CrossRef]

21. Gavrieli Y, Sherman Y, Ben-Sasson SA. Identification of programmed cell death in situ via specific labeling of nuclear DNA fragmentation. J Cell Biol 1992; 119: 493-501. [CrossRef]

22. Grasl-Kraupp B, Ruttkay-Nedecky B, Koudelka H, Bukowska K, Bursch W, Schulte-Hermann R. In situ detection of fragmented DNA (TUNEL assay) fails to discriminate among apoptosis, necrosis, and autolytic cell death: a cautionary note. Hepatology 1995; 21: 1465-8. [CrossRef]

23. Negoescu A, Lorimier P, Labat-Moleur F, Drouet C, Robert C, Guillermet C, Brambilla C, Brambilla E. In situ apoptotic cell labeling by the TUNEL method: improvement and evaluation on cell preparations. J Histochem Cytochem 1996; 44: 959-68. [CrossRef]

24. Negoescu A, Guillermet C, Lorimier P, Brambilla E, Labat-Moleur F. Importance of DNA fragmentation in apoptosis with regard to TUNEL specificity. Biomed Pharmacother 1998; 52: 252-8. [CrossRef]

25. Duran EH, Gürgan T, Günalp S, Enginsu ME, Yarali H, Ayhan A. A logistic regression model including DNA status and morphology of spermatozoa for prediction of fertilization in vitro. Hum Reprod 1998; 13: 1235-9. [CrossRef]

26. Evenson D, Jost L. Sperm chromatin structure assay is useful for fertility assessment. Methods Cell Sci 2000; 22: 169-89. [CrossRef]

27. Fernández JL, Muriel L, Rivero MT, Goyanes V, Vazquez R, Alvarez JG. The sperm chromatin dispersion test: a simple method for the determination of sperm DNA fragmentation. J Androl 2003; 24: 59-66.

28. Chohan KR, Fiffin JT, Lafromboise M. Sperm DNA damage relationship with embryo quality and pregnancy outcome in IVF patients. Abstracts of the Scientific Oral and Poster Sessions Fertility Sterility 2004; 82: S55.

29. Check JH, Graziano V, Cohen R, Krotec J, Check ML. Effect of abnormal sperm chomatin structural assay on pregnancy outcome following IVF with ICSI in previous IVF failures. Arch Androl. 2005; 51: 121-4. [CrossRef]

30. Bungum M, Humaidan P, Spano M, Jepson K, Bungum L, Giwercman A. The predictive value of sperm chromatin structure assay (SCSA) parameters for the outcome of intrauterine insemination, IVF and ICSI. Hum Reprod 2004; 19: 1401-8. [CrossRef] 
31. Larson-Cook KL, Brannian JD, Hansen KA, Kasperson KM, Aamold ET, Evenson DP. Relationship between the outcomes of assisted reproductive techniques and sperm DNA fragmentation as measured by the sperm chromatin structure assay. Fertil Steril 2003; 80: 895-902. [CrossRef]

32. Virro MR, Larson-Cook KL, Evenson DP. Sperm chromatin structure assay (SCSA) parameters are related to fertilization, blastocyst development, and ongoing pregnancy in in vitro fertilization and intracytoplasmic sperm injection cycles. Fertil Steril 2004; 8: 1289-95. [CrossRef]

33. Spanò M, Bonde JP, Hjøllund HI, Kolstad HA, Cordelli E, Leter G. Sperm chromatin damage impairs human fertility. The Danish First Pregnancy Planner Study Team. Fertil Steril 2000; 73: 43-50. [CrossRef]
34. Evenson DP, Jost LK, Marshall D, Zinaman MJ, Clegg E, Purvis K, et al. Utility of the sperm chromatin structure assay as adiagnostic and prognostic tool in human fertility clinic. Human Reproduction 1999; 14: 1039-49. [CrossRef]

35. Henkel R, Kierspel E, Hajimohammad M, Stalf T, Hoogendijk $\mathrm{C}$, Mehnert C, et al. DNA fragmentation of spermatozoa and assisted reproduction technology. Reprod Biomed Online 2003; 7: 477-84. [CrossRef]

36. Henkel R, Hajimohammad M, Stalf T, Hoogendijk C, Mehnert C, Menkveld $\mathrm{R}$, et al. Influence of deoxyribonucleic acid damage on fertilization and pregnancy. Fertil Steril 2004; 81: 965-72. [CrossRef]

37. Caglar GS, Köster F, Schöpper B, Asimakopoulos B, Nehls B, Nikolettos $\mathrm{N}$, et al. Semen DNA fragmentation index, evaluated with both TUNEL and Comet assay, and the ICSI outcome. In Vivo 2007; 21: 1075-80. 